\title{
DOSSIE
}

\section{Participação política e democracia}

\author{
Silvana Krause*
}

\section{Apresentação}

A revista Sociedade e Cultura, do Departamento de Ciências Sociais da U niversidade Federal de Goiás, apresenta nesta edição um dossiê sobre participação política e democracia. M uito se tem debatido, na ciência política, a respeito da crise e dos limites da democracia representativa e vários são os caminhos apontados sobre suas causas e conseqüências. Também são ressal tados no debate diversas matrizes teóricas que objetivam buscar al ternativas para o dilema, que é vivenciado tanto nas democracias ocidentais consideradas maduras, quanto nas novas democracias instaladas no ritmo conhecido da "terceira onda".

0 artigo de $\mathrm{M}$ arcello Baquero e M aria Sallete Souza A morim apresenta uma reflexão sobre a importância de uma cultura política democrática para a consolidação da nova democracia brasileira. B aseando-se em dados empíricos e partindo de uma concepção que demonstra os limites da " [...] simples institucional ização de regras e normas democráticas num contexto de agravamento social [...]", os autores diagnosticam uma cultura política fragmentada, na qual permanecem predominantemente valores tradicionais da cultura política brasileira, que não fortalecem a legitimidade e a credibilidade da nova democracia no país. Marcelo e M aria Salete oferecem como alternativa ao diagnóstico de uma cul tura política fragmentada o conceito

* Professora adjunta do Departamento de Ciências Sociais da Universidade Federal de Goiás. de capital social que possa fomentar uma cultura política participativa, promovedora de confiança recíproca e solidariedade social entre os cidadãos.

A nalisar especificamente a participação e mobilização civil no estado do Rio Grande do Sul contra a liberação dos transgêni cos no $B$ rasil é 0 objetivo do artigo de Ronaldo Botelho. 0 autor fundamenta sua argumentação utilizandose de aportes teóricos que apontam os limites da perspectiva minimal ista de democracia, sem, contudo, deixar de considerar que a perspectiva participacionista também deve ser avaliada com um olhar crítico. Ronaldo percebe, em seu estudo de caso, a importância do terceiro setor para a mobilização da sociedade civil, quando afirma que " $[. .$.$] o denominado terceiro setor$ ocupa um espaço estratégico no sentido de encurtar as distâncias existentes entre indi víduos excluídos do processo de tomada de decisões". I mportante também é sua percepção de que se desenvolvem, nesse tipo de ações participativas, novas perspectivas de organização e atuação política na sociedade brasileira.

Com o objetivo central de refletir sobre o processo de descentral ização político-administrativa implementado especialmente a partir da constituição da "N ova R epública" brasileira, os autores Washington Luís de Sousa Bonfin, $M$ arysol A lves de Oliveira el rismar $N$ ascimento da Silva debruçam-se em uma anál ise da capital do Piauí (Terezina), observando dois conselhos gestores municipais (assistência social e da criança e adolescente). A contribuição do artigo é demonstrar, com base em estudos de caso, 
que a descentral ização dos processos decisórios nem sempre incentiva e fortalece a participação política e 0 acesso aos recursos públicos de setores da sociedade mais excluídos. Os autores salientam uma série de fatores que explicam a manutenção de concentração de recursos públicos e serviços nas mãos de grupos mais organizados, propondo al ternativas que possam al terar essa situação de fragilidade de participação da sociedade civil. Por último, temos 0 artigo de
J osadac Bezerra dos Santos, que tem como ponto central uma reflexão sobre o conceito de democracia agonística de Chantal M ouffe. 0 autor avalia a importância de incorporar na análise dos novos movimentos sociais uma perspectiva de definição de democracia que considere o pluralismo e 0 antagonismo como essenciais e que as instituições tenham novas respostas diante dos novos conflitos advindos de uma perspectiva plural radical. 